Article

\title{
Profile of Green Consumers in Romania in Light of Sustainability Challenges and Opportunities
}

\section{Teodora Roman ${ }^{1, \dagger}$, Ionel Bostan ${ }^{2, \dagger, *}$, Adriana Manolică ${ }^{1, \dagger}$ and Iustin Mitrica ${ }^{1, \dagger}$}

1 Department of Management, Marketing and Business Administration, Alexandru Ioan Cuza University of Iaşi, Bulevardul Carol I 11, 700506 Iasi, Romania; E-Mails: teodoraroman@gmail.com (T.R.); manolicaa@yahoo.com (A.M.); iustin.mitrica@yahoo.com (I.M.)

2 Doctoral School of Economics, Stefan cel Mare University of Suceava, Str. Universitatii 13, 720229 Suceava, Romania

$\dagger$ These authors contributed equally to this work.

* Author to whom correspondence should be addressed; E-Mail: ionel_bostan@yahoo.com or ibostan@seap.usv.ro; Tel.: +40-230-216-147.

Academic Editor: Marc A. Rosen

Received: 23 February 2015 / Accepted: 15 May 2015 / Published: 26 May 2015

\begin{abstract}
Sustainability and responsible consumption are now the policies of companies interested in preserving a good reputation. If in the past, sustainability was an issue present only in the corporate social responsibility campaigns developed by companies; nowadays, this aspect has become a key element that has been proven to influence the purchasing behavior of consumers. The existence of policies and strategies in the area of sustainability does not necessarily mean their being put into practice as long as people, who make these objectives attainable, are not aware of them. The present paper aims to explore the green consumption of Romanian consumers, which would indicate whether the concern for environmental problems is then translated into an appropriate behavior; in other words, whether "words become facts". At the same time, this paper analyzes the extent to which the "green trend" has gained popularity in Romania, how involved the Romanian consumers are with environmental issues and the behaviors they adopt in order to mitigate the impact on the ecosystem. However, there are differences between individual opinions on green consumption and the actual behavior adopted in trying to ameliorate this issue.
\end{abstract}


Keywords: sustainability; green consumer; environment

\section{Introduction}

The sustainability concept is associated with a wide range of human activities related to resource use, including natural, human and financial ones, having the certainty of its continuity and that these activities will be performed during an unlimited period of time [1]. According to Hasna [2], sustainability refers to the development of all aspects of human life that affect subsistence.

The production and consumption of goods and services represent the main drivers of economic growth, contributing to a great extent to the improvement of life quality, but they can also harm it. The way in which a population produces and consumes expresses implicitly its development level and awareness of environmental problems. At the global level, the planetary-scale development of certain activities has already generated a high level of pollution and global warming; the depletion of some natural resources has been determined, and this has seriously threatened the maintenance of biodiversity. As a rule, the negative impact of production and consumption activities is accentuated through the increase of population and per capita consumption.

In a nutshell, sustainable consumption implies "the use of goods and services which satisfy the basic needs and enable a better life quality and at the same time the minimization of the consumption of natural resources, the generation of toxic materials and waste and pollutants over a life cycle, so that there is no risk of the impossibility to satisfy the needs of future generations" [3]. Sustainable consumption imposes the satisfaction of social needs only at the level of a decent life and, on the contrary, does not affect the increase in life quality. It can only take place through the efficient use of resources, the use on a large scale of reusable energy and minimization of waste. This wish involves the change of the characteristics of demand and, implicitly, of certain elements that are related to the dominant lifestyle, especially in economically-developed countries. The supply of the same services or of qualitatively superior services that could respond to the decent needs of life and even the aspirations of the improvement of life quality, at the same time as ending the deterioration of the natural environment, raise not only the problem of the change of some consumption models, but also that of the reduction of the quality of goods and services consumed, even if the last one seems to be more difficult to accomplish.

Since the 1970s, the theories concerning "green" or "sustainable" consumption have influenced both the market's and the consumers' preferences and also determined that some environmental organizations actually influence the population towards adopting a more eco-friendly behavior [4]. Scientists who studied green/sustainable consumption concluded that the access to information, societal values and attitudes all influence the consumer's behavior. Social sciences analyzed the way in which the social status of a person could be a factor in determining a predisposition towards green/sustainable consumption, taking into consideration the personal feelings of those who adopt such a behavior. Even if the archetype of the human being seems to reflect a pro-environmental ethos, green consumption is often used by people as a signaling instrument of their social status. However, a high social status obtained only through green consumption is often criticized, as many of the people 
involved in the fight to protect the environment do so by purchasing many products that are only believed to be "green", but in actuality are not and, in some cases, are even harmful to the environment.

Throughout the years, several definitions for environment protection and green consumption have been proposed. For some people, "green" means an attitude. Some consumers that are interested in this issue see the deterioration of the present environmental conditions as a problem for global security. Others, who are not affected as much by environmental problems, believe that these issues will sort themselves out eventually. The socially responsible consumer is the one who is aware of his impact on the environment and has the power to make a change through his behavior. This definition is centered on social involvement, promoting the idea that a green consumer should be up to date with all social problems, should believe in his power to make a change and should be actively involved in a community. The aim of adopting such a behavior is either to manifest a positive influence or to reduce the negative impact on the environment. For others, just being aware of environmental problems represents an action or a change in behavior. At an organizational level, this could translate into the production of goods that are eco-friendly and that reduce the impact on the environment. At the level of consumer behavior, the definition could be adjusted to highlight the way in which one person can reduce the negative influence on the environment. Thus, the awareness of green consumption has more of a social side, and the definition could be reformulated to reflect a more long-term focus on the well-being of the individual and the society as a whole through the reduction of the negative consequences associated with a certain product.

Studies [5-7] showed that the orientation towards being a green consumer is connected to education and social status. Many of those who studied green or sustainable consumption tried to find the explanation of this behavior: which green products do people buy, how many and why? These studies analyzed the consumption as the result of some sets of well-rooted principles and wishes of the human being. The question the sociologists and other researchers interested in social problems ask is: what does green consumption entail for these people and how does this penchant reflect and reproduce social differences? Instead of quantifying and trying to find a behavioral model, the accent that falls on the social status raises questions regarding the symbolic and cultural meaning of this consumption practice. When examining this behavior, each person's intentions translate a combination between "to say" and "to do": not only the practical activity to consume something, but also its representations [8].

Given that the basic idea of marketing is to center the entire business model on the needs and requirements of the consumer, finding out the identity of the "green consumer" is crucial. However, all those employing this strategy should first question if this business model has an actual basis in reality and is not just a fashionable trend, as well as if this "green consumer" actually exists or if he is just a myth [9].

Studies have shown that the typical green consumer is educated and influential. He is between the ages of 30 and 49 and has children aged six or older [10].

Once companies understood the external pressures to improve their eco-performance and to become "greener", the green consumer has become the center point for the development of so-called "green marketing". The marketing professionals tried to identify and understand the needs of this new type of consumer in order to provide him with offers that met his demands. 
Over time, the green consumer was characterized as a person who changes his mind very quickly and who can give up on a product at any point if it does not protect the environment. In a metaphorical way, he is seen as a "creature" that hibernates most of the time and only wakes up to give support to an environmental cause. Others see him as being part of small, but well-organized groups. These groups represent a segment of "ultra-green" consumers whose goal is to boycott certain products in order to change the policy regarding environmental protection of the companies that produce them [11]. Many analysts claim that this group will substantially increase in numbers in the upcoming years and will become the priority target for numerous companies.

Understanding the demographic aspects of green consumption can help businessmen to communicate better with this category of consumers. The green consumer is considered to be a sincere person, with a high level of dedication towards a green lifestyle. He understands the reality concerning the practices of a company and their impact on the environment and does not expect perfection, but rather small steps towards sustainability and becoming greener. The green consumer understands that the process to become eco-friendly should not require major sacrifices and tends to be skeptical, unless strong supporting evidence is provided, when companies boast about environmental protection

The current paper aims to analyze the extent to which the green trend entered Romania, the degree of involvement of the Romanian consumers regarding environmental problems and the behaviors they adopt to diminish the impact on the ecosystem. Each person has certain opinions about a situation, in this case about green consumption, but at the same time, there can be differences between the way of thinking and real behavior.

\section{Literature Review}

Green marketing thought the Western, developed nations was at a similar place in the mid- to late-1970s. After a flurry of conceptual papers to initiate the field of study, the research trends at the time focused on many of the same issues, including the classification of the green consumer and determining the segment's attractiveness to industry [9,12-15]. The results of these studies were often inconclusive or contradictory, much like the recent research from emerging markets.

It is widely accepted that a competitive advantage in the field of business can be easily gained if the goal of the innovations being worked on is focused on the protection of the environment. Settling the concerns of the consumers regarding the eco-friendliness of the product is a "win-win" strategy both for a corporation, but also the environment [16].

The latest theories began to promote win-win solutions, stressing the idea of creating environmentally-suitable products that are technically the same if not better than conventional products. However, in fact, most often, this does not happen. Recent studies $[15,17,18]$ suggest that even the greenest consumers are increasingly willing not to accept higher prices for these products, but rather to change their way of life.

Table 1 lists all of the studies used in the secondary research stage and helps formulate the objectives and hypotheses for the present study. 
Table 1. Brief presentation of the literature review.

\begin{tabular}{|c|c|c|c|c|}
\hline $\begin{array}{l}\text { Nr. } \\
\text { crt. }\end{array}$ & References & Year & Method & Results \\
\hline 1 & [13] & 2008 & $\begin{array}{l}887 \text { self-administered } \\
\text { questionnaires, } \\
\text { persons aged over } \\
18 \text { years }\end{array}$ & $\begin{array}{l}\text { - the consumers' participation in environmental } \\
\text { protection is made possible through electricity and } \\
\text { water saving, which can be associated with an } \\
\text { economic behavior; the Portuguese consumers } \\
\text { have information about environmental issues. }\end{array}$ \\
\hline 2 & {$[12]$} & 2009 & essays: 51 subjects & $\begin{array}{l}\text { - women are more preoccupied by environmental } \\
\text { problems than men; } \\
\text { - the identification of three different personalities: } \\
\text { the "anti-hero", the "environment hero" and the } \\
\text { "anarchist"; } \\
\text { - green consumption is a task that everyone should } \\
\text { fulfil on his own, at the same time as, but not } \\
\text { together with, other consumers. }\end{array}$ \\
\hline 3 & [14] & 2009 & $\begin{array}{c}\text { survey: } 534 \text { subjects } \\
\text { Taiwan }\end{array}$ & $\begin{array}{l}\text { - loyalty towards a "green" brand is related to its } \\
\text { perceived value, to the satisfaction and confidence } \\
\text { the consumer has in green products; these } 3 \text { aspects } \\
\text { represent the key to getting a loyal customer. }\end{array}$ \\
\hline 4 & [19] & 2004 & $\begin{array}{l}\text { in-depth interviews of } \\
14 \text { subjects }\end{array}$ & $\begin{array}{l}\text { - all of the persons recycled, but not all the } \\
\text { same quantity; } \\
\text { - some of the participants cultivated organic products } \\
\text { on their own; others bought second-hand clothes; } \\
\text { - most of the subjects buy green products from the } \\
\text { big supermarkets due to the large offering, but } \\
\text { there are also persons who buy from private } \\
\text { persons who produce "green" products. }\end{array}$ \\
\hline 5 & [20] & 2010 & $\begin{array}{l}\text { survey: } 1832 \\
\text { questionnaires } \\
\text { Sweden }\end{array}$ & $\begin{array}{l}\text { - both the adoption of "green" innovations and the } \\
\text { daily routine were significantly determined by } \\
\text { values, beliefs and the purchasing behavior; } \\
\text { a positive correlation was established between the } \\
\text { previously adopted eco-innovations and the wish } \\
\text { for a future adoption. }\end{array}$ \\
\hline 6 & [21] & 2001 & exploratory research & $\begin{array}{l}\text { - this identifies the ways in which it can attract a } \\
\text { green consumer. }\end{array}$ \\
\hline 7 & {$[22]$} & 2008 & $\begin{array}{l}6010 \text { questionnaires } \\
\text { applied to teenagers }\end{array}$ & $\begin{array}{l}\text { - the green purchasing behavior is determined by } \\
\text { social influences, by the preoccupation with the } \\
\text { environment, by the image one has in society and } \\
\text { by the perceived responsibility. }\end{array}$ \\
\hline 8 & [23] & 2012 & $\begin{array}{l}\text { experiment: } 50 \\
\text { subjects, USA }\end{array}$ & $\begin{array}{l}\text { - the social campaigns of the brands do not influence } \\
\text { the consumers' social behavior; the loyal consumers } \\
\text { intend to preserve energy only if the favorite brand } \\
\text { has a history in this area. }\end{array}$ \\
\hline
\end{tabular}


Table 1. Cont.

\begin{tabular}{|c|c|c|c|c|}
\hline $\begin{array}{l}\text { Nr. } \\
\text { crt. }\end{array}$ & References & Year & Method & Results \\
\hline 9 & [24] & 2012 & $\begin{array}{l}233 \text { questionnaires } \\
\text { with Likert scale } \\
\text { questions }\end{array}$ & $\begin{array}{l}\text { - age influences the consumers' intention to purchase } \\
\text { green products; } \\
\text { - those over } 45 \text { years did not have as much } \\
\text { knowledge about environmental issues; } \\
\text { - the young have a greater preoccupation with the } \\
\text { environment, but they are more sensitive to the } \\
\text { price of green products. }\end{array}$ \\
\hline 10 & {$[25]$} & 2006 & online survey, USA & $\begin{array}{l}\text { - the identification of green consumers, the } \\
\text { demographic characteristics of green consumers, } \\
\text { successful green products. }\end{array}$ \\
\hline 11 & {$[15]$} & 2012 & $\begin{array}{l}\text { questionnaires } \\
\text { applied to students } \\
\text { from } 3 \text { countries }\end{array}$ & $\begin{array}{l}\text { - the government, companies and the media have } \\
\text { positive effects on the adoption of green behavior. }\end{array}$ \\
\hline 12 & [17] & 2010 & $\begin{array}{c}\text { survey: } 455 \text { subjects } \\
\text { USA }\end{array}$ & $\begin{array}{l}\text { - there is a niche in the market for "green" } \\
\text { restaurants with a huge potential; } \\
\text { - the clients agree that restaurants should help in the } \\
\text { protection of the environment; they are also willing } \\
\text { to pay more for organic food at the restaurant. }\end{array}$ \\
\hline 13 & {$[18]$} & 2011 & $\begin{array}{l}\text { survey: } 323 \text { subjects, } \\
\text { Taiwan }\end{array}$ & $\begin{array}{l}\text { - the "green" factor counts in the purchasing } \\
\text { decision; the consumers' income has a moderate } \\
\text { effect on this decision; the value of green products } \\
\text { is better perceived in the case of consumers with a } \\
\text { higher income. }\end{array}$ \\
\hline 14 & [26] & 2005 & $\begin{array}{l}\text { interview: } 81 \text { subjects } \\
\text { Great Britain }\end{array}$ & $\begin{array}{l}\text { Three "green" purchasing criteria of electronic devices: } \\
\text { - they protect the environment; } \\
\text { - the materials they are made from; } \\
\text { - their second-hand availability. }\end{array}$ \\
\hline
\end{tabular}

We have selected a number of 14 relevant studies in order to help us define our steps. These researchers have chosen to identify issues related to green purchasing decisions, green products, the impact of income on green consumption and the influence of the government, NGOs and the media on increasing the green orientation. Their conclusions were a starting point in our démarche.

\section{Materials and Methods}

In the context of the economic crisis, being a green consumer is a luxury for a great part of the population. Taking into account that when buying ecological products and adopting a green behavior, the benefits are noticed in the long term, most consumers still choose traditional products depending on the price and the immediate advantages. Green consumption implies various aspects, such as the attitude and behavior towards the environment and motivations. In order to perform a better segmentation, it is important to identify the target public of green products and, at the same time, to separate these features. 
The objectives of this paper are the following:

- The identification of the degree to which the Romanian consumers are preoccupied by environmental problems;

- Highlighting the extent to which the Romanian consumers adopt a green purchasing behavior;

- The analysis of the relationship between the preoccupation for environmental problems and the decision to buy green products;

- The examination of the relationship between demographic variables (age, income, education, gender) and green consumption.

The relationship between certain demographic variables and green consumption was studied by several authors who highlighted that young people are more sensitive to environment problems than the elderly. Previous research [27] indicated that green consumers are aged 30-44 years. At the same time, people over 45 years have less knowledge about the environment, but they are eager to pay more for the purchase of ecological products. On the other side, those aged between 18 and 45 years are more sensitive to price, but they have more solid knowledge about environmental problems. Therefore, the first conclusion would be:

H1: The young are more sensitive to environmental problems than the elderly $[13,24]$.

As for a person's gender, research has shown that women are more sensitive and more preoccupied about environmental problems, but there is no consensus on this matter. As a consequence, the starting hypothesis is:

$\mathrm{H} 2$ : Women are more inclined to have a green purchasing behavior than men $[13,28]$.

Referring to the level of education and income, the higher these are, the higher the level of preoccupation towards environmental problems is, because there is a higher purchasing power and, at the same time, more knowledge related to environment issues, as well as a higher impact of people's actions on nature. Therefore, the hypotheses used in this paper are:

H3: There is a direct relationship between people's education level and the preoccupation with the environment $[13,24]$.

H4: A person's income significantly influences the decision to purchase green products [13,28].

This paper has first and foremost a descriptive character, since it verifies certain hypotheses that resulted from previous studies, but it also has a strongly exploratory nature, because it aims to shape Romanians' green consumption behavior.

The sampling method chosen is the quota one, using two variables, sex and age. The quotas were set taking into account the population distribution at the national level [29]. Men represent $49.6 \%$ of the population, while the rest are female. Men under 40 years represent $26.8 \%$, and men over 40 years $21.9 \%$. As regards women, those under 40 years represented $25.5 \%$, and those over 40 years $25.8 \%$. The 40 year threshold was set taking into consideration that the topic of green consumption is relatively new in the current society, and there are differences regarding the information and knowledge level in this field. 
For the quantitative survey, the tool used was the questionnaire (applied to 150 respondents), made up of 23 questions formulated in such a way as to solve the objectives and to test the hypotheses. The questions included all types of scales and especially continuous ones in order to make correlations among variables. The questionnaire comprised both open and closed questions, with a single or multiple choice answers, ranking answers, expressing the agreement or disagreement level, as well as grade awarding answers. The first questions in the questionnaire included statements about the interest in the environment and in the main problems that the current society is facing. The next questions referred to green purchasing behavior, from the time period needed to purchase the goods to the reasons for such behavior, as well as the concrete actions for its manifestation. Lastly, there are questions for the identification of the respondent, with a demographic character, necessary to test the hypotheses initially established.

The parameters used in this survey, in an attempt to understand consumption intentions, are sex and age. In Romania, men represent $49.6 \%$ of the population, while the rest are women.

As regards age, the population was split into two categories: persons under and those over 40 years old. Taking into consideration that the topic of green consumption is a relatively new concept in the present society, differences in the degree of information and knowledge about this field can be observed. At the end of the year 2010, the population in Romania was 21,431,298, of which 5,741,979 were men under the age of 40 and 4,692,164 were men over the age of 40, which in percentages translates to $26.8 \%$ and $21.9 \%$, respectively. As for women, the numbers were 5,476,119 (25.5\%) under 40 and 5,521,036 (25.8\%) over.

A quota sampling method was chosen, using two variables: sex and age. Of the total of 150 persons that were surveyed, 74 were male and 76 female, and for each age group, they were distributed as shown in Table 2.

Table 2. Distribution of survey participants by age and sex.

\begin{tabular}{cccc}
\hline Gender & Total & Under 40 years & Over 40 years \\
\hline Male & 74 & 40 & 34 \\
Female & 76 & 38 & 38 \\
Total & 150 & 78 & 72 \\
\hline
\end{tabular}

The study also did a field survey in parks and crowded areas near large supermarket chains. We chose this method due to some of the advantages it provides:

- the answer rate is higher than in the case of other types of surveys due to the questioner's presence;

- the questioner can provide additional explanations;

- the possibility to come into direct contact with the respondents and to make the proposed segmentation.

However, the disadvantages of such a field survey are:

- the weather conditions, which can slow down the data collection process;

- the reluctance of people that are asked to stop in order to answer questions;

- providing answers that are not true, out of a desire to follow general trends;

- the refusal to provide personal data, which may lead to the invalidation of the questionnaire. 
The current research presents certain significant limits, which should be taken into account in the interpretation of the results. Thus, one of them refers to the fact that the sampling method is a subjective one, by quotas; the representativeness is not guaranteed, and the potential features are not taken into consideration. The age of the people surveyed is also a limit, because all of the persons are over 20 years old, which implies that other age categories cannot be considered as having the same green consumption behavior.

\section{Results}

As for the research results, these are analyzed in compliance with the objectives set firstly. Thus, the first goal implies the degree to which the consumers are preoccupied with environmental problems. One of the questions lists the main problems the environment has to face nowadays, and the respondents are asked to select three variants they consider the most serious. Thus, of a total of 450 choice variants, 78 were directed to global warming, 61 acid rain, 74 fuel crisis, 68 waste of resources, 53 hole in the ozone layer, 32 deforestation, 43 pollution and 41 natural hazards. As a consequence, the main three problems the Romanian consumers perceive as being the most serious ones in the environment are the global warming phenomenon, the fuel crisis and the waste of resources. Graphically, the respondents' choices are expressed in Figure 1.

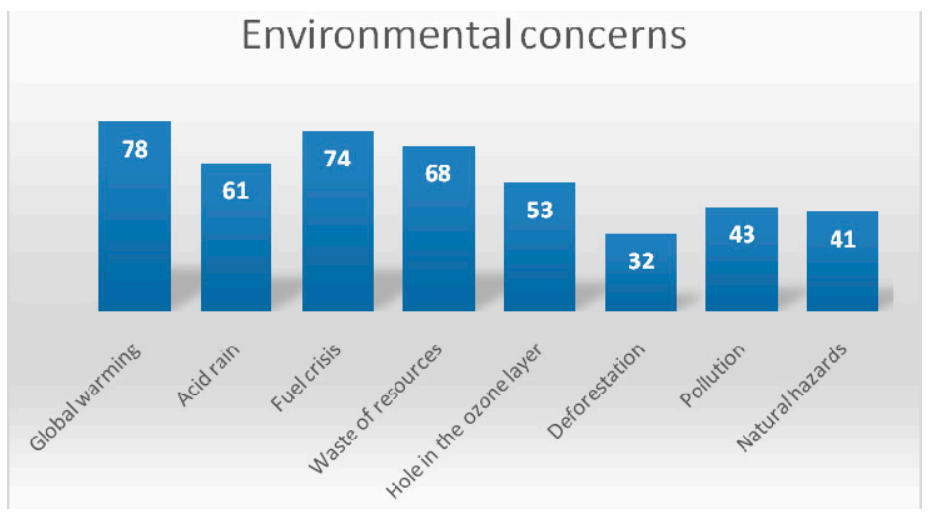

Figure 1. The distribution of the main environmental concerns.

In relation to the environmental concerns, the respondents expressed their degree of agreement and disagreement about certain statements about their behavior related to the environment (Figure 2).

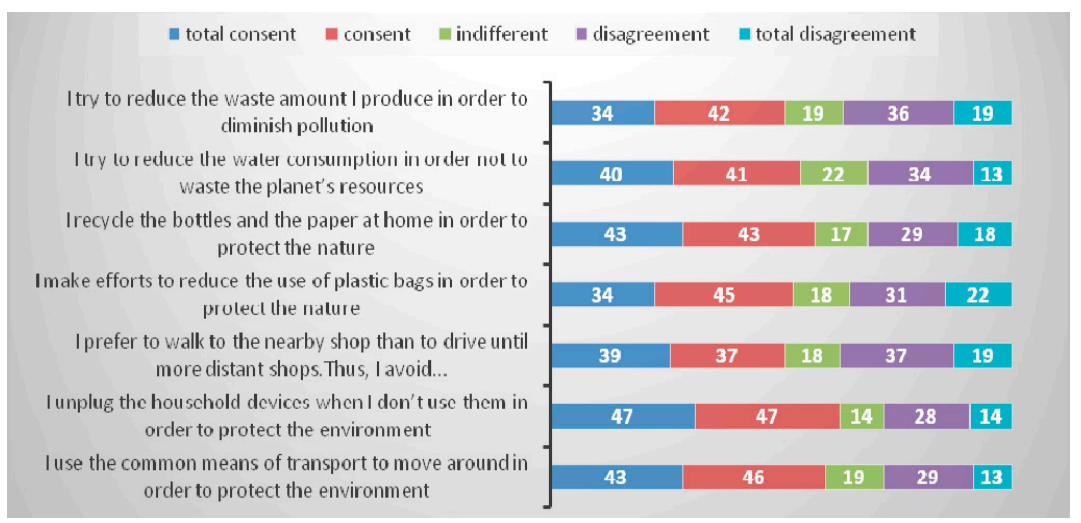

Figure 2. Respondents' preoccupation with the environment. 
As can be noticed from the graph above, respondents prevalently agree or totally agree with all of the statements concerning their behavior, which means they are preoccupied with environmental problems. Despite this, since it is a sensitive topic and the proof of good behavior in society, these results could be valid only at the declarative level, and in reality, they are not put into practice.

Concerning environmental preoccupation, the respondents had the possibility to award grades from one to 10 for different statements related to the implementation in Romania of environmental protection programs and to the extent to which green consumption is promoted.

One may conclude that respondents believe to a great extent that the natural environment in Romania must be protected, that in order to do this, large amounts of money should be spent and that the public needs to be informed about all of these problems in order to trigger an alarm signal. What is desired in fact is a change in people's behavior, which is why the average for personal involvement in environmental problems is high, occupying third place in importance. The lowest average belongs to the promotion of green consumption in Romania, which may indicate slight reluctance towards the strict adoption of ecological consumption behavior.

Another objective of the research refers to the degree to which respondents adopt a green purchasing behavior. When they had to list the green products they bought, the answers were very diverse; their quantification is available in the graph in Figure 3.

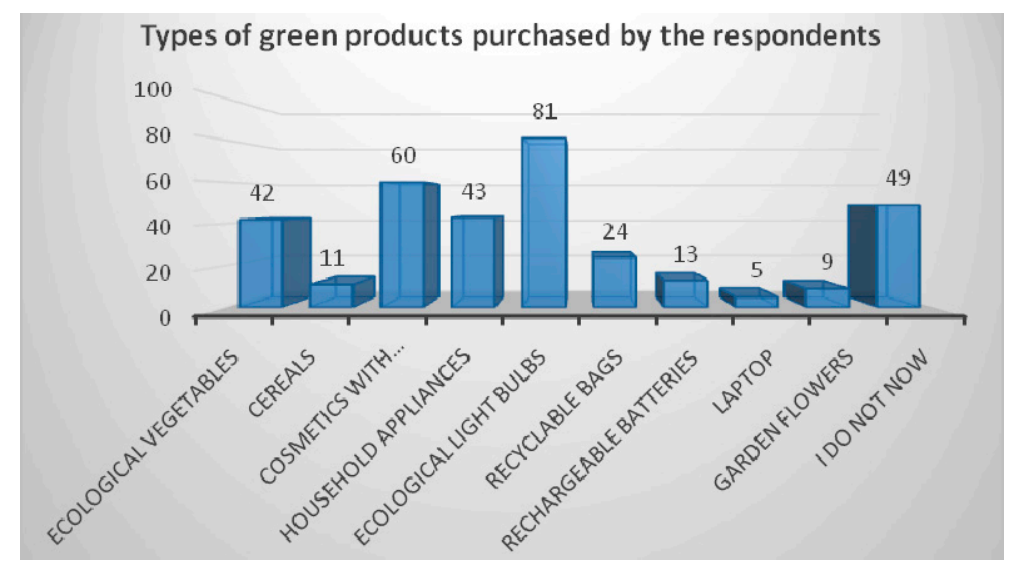

Figure 3. Types of green products purchased by the respondents.

Those questioned had difficulties in listing three green products, most of them only mentioning one or two. Among the listed products, there were also some that were not green products, which may mean that the respondents are not very familiar with the green products concept, even though in the beginning, their definition was explained to them.

As regards the availability to pay more for a green product, the results indicated that $65 \%$ of the respondents would do that, and out of these, most (53.6\%) would take out of their pocket a sum smaller than $5 \%$ of the product's value, while $32.1 \%$ would pay more by 5 to $9 \%$ of the product's price. Of the questioned people, only one person would want to offer more than $19 \%$ of the price for a green product.

Regarding the degree of information on the impact the products have on the environment, each person has or does not have some knowledge about it. The results indicate the following: $32.66 \%$ of the respondents have plenty or a lot of information, but most of them have little knowledge or even 
none, which means that people are not informed about the impact on the environment. This is in contradiction somehow with an ecological purchasing behavior. On the other hand, this might be the lack of information resulting from the insufficient promotion by companies of the information regarding the products they sell (Figure 4).

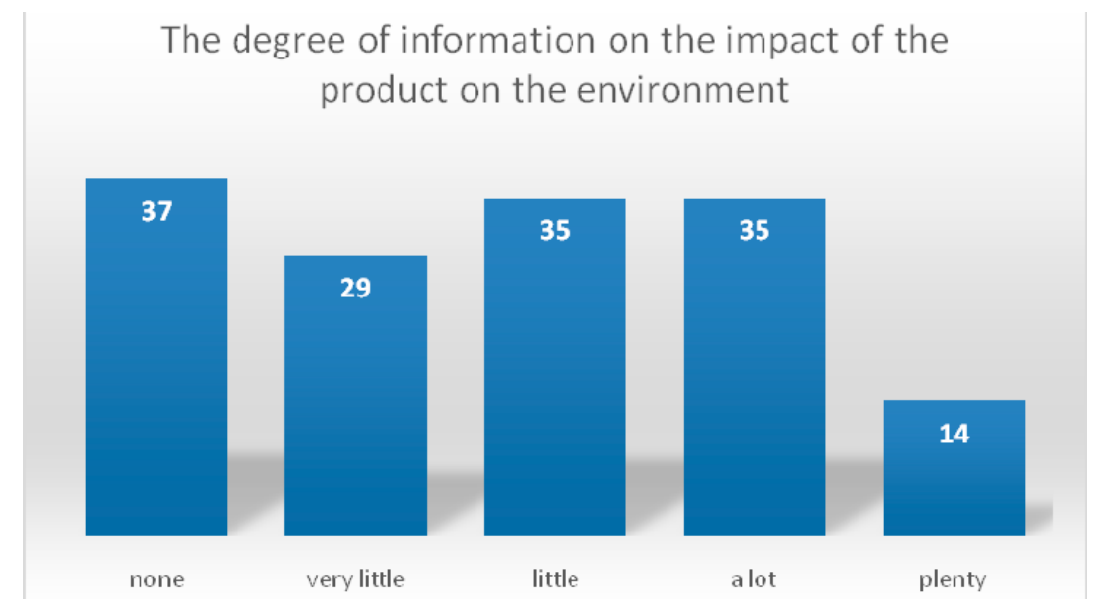

Figure 4. The degree of information on the impact of the product on the environment.

When the purchase takes place, several criteria are taken into consideration. The respondents were asked to distribute 100 points among several characteristics according to the degree to which they take them into account in the purchasing decision. The averages of the points awarded for each feature are found in the table below. As can be observed, what counts the most is the ratio quality/price and the price itself, and to a lesser extent, there is interest in packaging, advertisement or the impact on the environment. This could signify that the declared intention to have an environmentally-friendly behavior is not really put into practice, since in the purchase decision, the impact on the environment is not taken into consideration much. These questions verify and test the respondents' consistency on the same variants expressed in different ways.

Another objective aims to analyze the relationship between the preoccupation with the environmental problems and the purchasing behavior. Normally, a proactive attitude towards the environment would lead to an appropriate behavior, oriented towards the protection of nature. After the regression analyses, the statements about different types of purchasing behaviors were taken as dependent variables, while the opinions about the environmental problems were considered independent variables. There was a situation when a correlation between the preoccupation for the environment and the purchasing behavior was identified. Thus, even if, initially, all of the variables concerning the perception about the environment were introduced, only in the case of the statement "I read the labels to see if the products are ecological", two variables proved to be significant, namely the improvement of environment quality and the necessity for better environment protection. The regression equation, after the introduction of only these variables, takes the form:

Reading the products' labels in order to check if they are ecological $=3.494+0.329 \times$ improvement of environment quality $+0.162 \times$ the need for more environment protection.

The value of the determination coefficient of $11.6 \%$ indicates that only by this weight does the variation of the independent variables explain the variation of the dependent ones; therefore, the 
decision to adopt a green purchasing behavior depends on other factors, not only on the concern with environmental problems.

A multiple linear regression analysis (Tables 3 and 4) highlighted that the confidence in the quality of ecological products is explained in a proportion of $7.1 \%$ by the fact that ecological products are not a whim and that they use healthy ingredients.

Table 3. Calculus elements for the regression Analysis I.

\begin{tabular}{ccccc}
\hline Model & R & R Squared & $\begin{array}{c}\text { Adjusted } R \\
\text { Squared }\end{array}$ & $\begin{array}{c}\text { Standard Error of } \\
\text { the Estimate }\end{array}$ \\
\hline 1 & $0.267^{\text {a }}$ & 0.071 & 0.059 & 1142 \\
\hline \multicolumn{4}{c}{${ }^{\text {a }}$ Predictors: (constant), healthy ingredients, are not a whim } \\
\hline
\end{tabular}

Table 4. The coefficients of the variables of the regression analysis.

\begin{tabular}{|c|c|c|c|c|c|c|}
\hline & \multirow[t]{2}{*}{ Model } & \multicolumn{2}{|c|}{$\begin{array}{c}\text { Unstandardized } \\
\text { Coefficients } \\
\end{array}$} & \multirow{2}{*}{$\begin{array}{c}\text { Standardized } \\
\text { Coefficients } \\
\text { Beta } \\
\end{array}$} & \multirow[t]{2}{*}{$t$} & \multirow[t]{2}{*}{ Significance } \\
\hline & & B & Std. Error & & & \\
\hline \multirow{3}{*}{1} & (Constant) & 2215 & 0.417 & - & 5317 & 0.000 \\
\hline & arenot_a_whim & 0.199 & 0.082 & 0.193 & 2422 & 0.017 \\
\hline & healthyingredients & 0.190 & 0.079 & 0.193 & 2422 & 0.017 \\
\hline
\end{tabular}

The last objective focuses on the identification of the relationships between the green behavior and the demographic variables. As regards the correlations among education, income and other types of behavior, a Spearman correlation test was applied, which indicated a positive, significant correlation between the income level and the attempt to reduce plastic bag use $(r=0.253, p=0.002)$. Taking into account that in the SPSS software (Version 19), the quantification was performed in an inversely proportional manner, meaning that a total disagreement level received a value of five, we may ascertain that the higher the income, the less effort people make to reduce the use of plastic bags (Table 5). Therefore, for them, it is not important that their use is not environment friendly. They shop a great deal, and they need those plastic bags. Comparing the needs behind each situation, we can observe that this is similar to Maslow's theory that says that we cannot ascend to a higher need until an inferior one is at least partially fulfilled.

Table 5. The correlation between the income and the reduction of the use of plastic bags.

\begin{tabular}{|c|c|c|c|c|}
\hline \multirow{6}{*}{ Spearman's rho } & \multirow{3}{*}{$\begin{array}{l}\text { I make efforts to } \\
\text { reduce the use of } \\
\text { plastic bags in order } \\
\text { to protect nature }\end{array}$} & Correlation Coefficient & 1000 & $0.253 * *$ \\
\hline & & Sig. (2-tailed) & - & 0.002 \\
\hline & & $\mathrm{N}$ & 150 & 150 \\
\hline & \multirow{3}{*}{ income } & Correlation Coefficient & $0.253 * *$ & 1000 \\
\hline & & Sig. (2-tailed) & 0.002 & - \\
\hline & & $\mathrm{N}$ & 150 & 150 \\
\hline
\end{tabular}

Note: $* *$ Correlation is significant (sig.) at the 0.01 level (2-tailed). 
One of the hypothesis mentioned that young people are more sensitive to environmental problems than more experienced persons. Green consumption is a fairly new concept, which is why it is necessary to make a distinction between two main population categories, those under 40 years and those over 40 years.

Taking into consideration that age and consent/disagreement degrees are ordinal variables, we analyzed their relationship by means of a correlation test based on the Spearman coefficient. The results indicated that between the respondents' age and the tendency to reduce the waste amount they produce, there is a significant, reduced intensity correlation $(p=0.017, \mathrm{r}=0.195)$, significant at a trust level of $95 \%$. The people under 40 are more preoccupied with reducing their waste amount than those over 40. Other correlations between age and the interest in the environment were found in the case of the use of common means of transport to reduce pollution, the unplugging of electrical devices when these are not operational, as well as the preference to walk to nearby shops without using a car, which pollutes a great deal. Thus, between age and preference to walk, there is a significant correlation, of low intensity ( $p=0.024, \mathrm{r}=0.184$ ), which expresses the fact that persons under 40 are more eager to walk to nearby shops, while people over 40 drive their car even for these trips.

Between age and the habit to unplug household devices, there is an inverse, significant correlation, of low intensity ( $p=0.007, \mathrm{r}=0.218$ ), which means that those under 40 years are more careless when it comes to unplugging devices. Finally, between age and the habit of using a common means of transport, there is a direct, significant correlation, of low intensity ( $p=0.001, \mathrm{r}=0.263$ ), which underlines that those under 40 are more dependent when it comes to using their personal car, while persons over 40 years use common transport when they move around. The rest of the statements above do not present significant correlations with age, since the significance values are higher than 0.05 .

One of the initially set hypothesis stipulated that women are more likely than men to have a green purchasing behavior. A chi-squared test of independence was applied, highlighting the following aspects: between a person's sex and the decision to stop using certain products for ecological reasons, there is a significant correlation, of low intensity $(\mathrm{df}=3, \mathrm{n}=150)=3.142, p=0.989$, chi $=0.032$; the same types of correlations exist between sex and the convictions and values of that person's family members not to purchase polluting products $(\mathrm{df}=3, \mathrm{n}=150)=5.335$; the purchase of ecological light bulbs $(\mathrm{df}=3, \mathrm{n}=150)=1.115$; and the purchase of less polluting products $(\mathrm{df}=3, \mathrm{n}=150)=4.365$. No significant purchasing behavior patterns were identified other than the ones correlated to the sex of a person. Women place higher value on these types of behavior than men do, which means that they are more inclined to adopt a green purchasing behavior.

Thus, even if initially, all of the variables concerning the perceived problems regarding the environment were introduced, only in the case of the statement "I read the labels to see if the products are ecological", two variables proved to be significant, namely the need to improve the quality of the environment and the necessity for a better protection of the environment. Therefore, the decision to adopt a green purchasing behavior depends on other factors, too, not only the ones concerning environmental problems. 


\section{Discussion}

Regardless of the strategies and policies elaborated and promoted at the international and national level, putting into practice and reaching the objectives concerning long-term sustainability depend on the end consumer and on his awareness degree, that each and every one should bring his contribution to the preservation of a clean environment and to avoid resource waste.

Our research shows that the first three problems of the environment considered the most serious ones by the respondents are global warming, fuel crisis and resource waste. This may indirectly point out that the fuels' price, as well as the price of other products increased due to the waste of resources.

More than half of the respondents agree or totally agree with various statements regarding green consumption. Thus, the main actions they perform are unplugging household appliances when these are not operational, paper and bottle recycling and the use of common transport. As for the correlation between demographic variables and environmental concern, significant correlations were observed between age and the attempt to reduce waste amount, using common transport for trips, unplugging devices and the preference to walk to neighboring shops, meaning that people under 40 are more inclined to an environmentally-friendly behavior than those over 40 years. There was a significant, positive correlation between income and the tendency to reduce plastic bags, highlighting that people with lower incomes are more inclined to saving; the real problem is if they do this in consideration of the environment or for financial reasons.

The three main measures that must be taken in relation to environment protection are: the improvement of environment quality, the information of the public concerning environmental issues and the personal implication of respondents in ecological problems. Regarding the behavior to purchase green products, the conclusions of our research are: when they had to list three types of green products that they bought, they encountered difficulties in listing exactly three products, while some of them also specified goods that are not included in the ecological category. Thus, the main three types of products purchased are ecological light bulbs and cosmetic products containing natural ingredients, and a relatively high percentage did not know any product. The first conclusion is that Romanians are not very involved in the purchase of green products, and therefore, their behavior is not favorable for the environment.

In order to shape the consumption behavior of green products, we tried to determine the time period when the last shopping for ecological products was performed. Again, the results are not very favorable, since most of the people bought green products four to six months ago and more than six months ago. Regarding the willingness to pay more for green products, only $56 \%$ of the questioned persons answered positively, and of these, more than a half would not pay an amount higher than 5\% of the initial sum. Thirty two percent of them would pay by $5 \%$ to $9 \%$ more, while the rest would pay higher percentages.

The respondents were given certain ecological purchasing behaviors for which they were asked to give grades on a scale from one to 10. All of the averages had high values, but the first three purchasing habits are: the reluctance to buy products from companies that are accused of pollution, purchasing products that do not pollute the environment and the reluctance to buy a product if the damages it has made to the environment are understood. As for the behaviors in relation to the person's sex, the comparison of averages given indicated that women awarded higher grades for these 
types of behaviors, suggesting that they are more involved in a green purchasing behavior, even if they are not as preoccupied with environmental problems as men. Therefore, the hypothesis according to which women are more inclined to a green purchasing behavior is true.

Of the respondents, $71 \%$ buy environmentally-friendly products on a regular basis, but no associations between income and the tendency to buy green products were discovered; as a consequence, the hypothesis according to which income positively influences the purchasing decision was not confirmed.

Before going shopping, most of the respondents do not have or have little information about the impact of products on the environment, which may suggest that a better promotion of ecological problems within the population is needed. The criteria that lie at the basis of purchasing the products, in the order of the point averages obtained, are: the ratio quality/price, then the price itself and, thirdly, the impact on the environment.

When speaking about the reasons why ecological products are considered to be better, the first place is occupied by the statement that they are healthier, followed afterwards by other features, in equal percentages: they are recyclable, have low energy consumption and the material of which the package is made.

Regarding the relation the respondents have with green products, firstly, they trust the ecological products; they believe they are beneficial; and at the same time, they agree that their prices are higher.

When it is about the hierarchy of the reasons why ecological products are bought, the situation is the following: in the first place, because they are healthy; second, because they reduce long-term expenses; third, because they have a positive impact on the environment; and last, they are in fashion.

A current problem is that of the ecological label, which is applied to products to signal that they have a reduced impact on the environment. As for the degree to which the Romanian consumers had seen/heard of the green label, $81 \%$ of these answered positively. The most important significance of such a label on a product is that the product is good for the environment.

Our research shows that the first three environmental problems considered by the respondents as being the most serious ones are: global warming, the oil crisis and resource waste. This can indirectly highlight that the price of oil and of other products increased due to the waste of resources. When correlated with the results obtained in the EC Eurobarometer study (2014), it can be ascertained that the problems of oil crisis and resource waste are elements that remain at the top of the list of priorities for Romanians when it comes to the protection of the environment [30]. More than half of the respondents agree in part or fully with various statements regarding green behavior. Thus, the main actions they undertake are: unplugging household appliances when they are not in use, recycling paper and plastic bottles and using public transport. These are correlated with the results of the study conducted at the European level, which shows that at the top of the list of actions undertaken on a daily basis that have as a goal the protection of the environment, the first three places are occupied by: sorting waste so that it can be recycled, reducing your home energy consumption and using public transport as much as possible instead of using your own car. 


\section{Conclusions}

As a general conclusion, we may ascertain that in Romania, consumers are accustomed to a great extent with the notion of green consumption, and many improvements to the information level and the influence to adopt such a behavior are possible. Since there is the willingness to adopt a conduct with a much reduced impact on the environment, but there is the problem of a too high price for ecological products and a lack of information, the positive attitude towards nature does not translate into an appropriate behavior.

Although there are attempts to save energy, to use common transport more frequently, to reduce the degree to which the environment is polluted due to personal actions and even though there is the intention to protect the environment, when it comes to the behavior of purchasing green products, things are not as positive.

The results of our research should trigger an alarm signal concerning the degree to which green consumption behavior is adopted and to push companies to increase marketing activities that should focus on environmental problems, as well as the fact that the products on the market have a reduced impact on the environment. Green marketing practices have recently increased, but we consider that the problem arises at the level of the population's income and information level, because people may purchase green products, but they are not aware of this aspect.

As the title implies, to become "green" is a matter of sustainability. Education is a very powerful means to develop a green orientation, but it will take time to change habits.

The most responsive age group tends to be young adults, many of whom are influenced by their children. In addition, women are a key target for greener products and often make purchases on behalf of men.

The best "green" customers are people with more money to spend. As a result, the most promising products for "greening" tend to be at the higher end of the market. The most promising outlets for green products are retail stores frequented by better-off shoppers.

In general, green consumers have the education and intellectual orientation to appreciate value; they will understand evidence that is presented in support of environmental claims.

\section{Acknowledgments}

The authors would like to thank the anonymous reviewers for their valuable comments and suggestions to improve the quality of the paper.

\section{Author Contributions}

The authors' contributions were equal. Ionel Bostan designed the research, its reasoning and drew conclusions. Teodora Roman did the literature review and the discussed data. Adriana Manolica collected and analyzed the data. Iustin Mitrica analyzed and discussed the data and performed the paper editing. All authors have read and approved the final manuscript.

\section{Conflicts of Interest}

The authors declare no conflict of interest. 


\section{References}

1. Marinova, D.; McGrath, N. Transdisciplinarity in teaching and learning sustainability. In Rationality in an Uncertain World; Banse, G., Hronszky, I., Nelson, G., Eds.; Edition Sigma: Berlin, Germany, 2005; pp. 275-285.

2. Hasna, A.M. Dimensions of sustainability. J. Eng. Sustain. Dev. Energy Environ. Health 2007, 2, $47-57$.

3. World Business Council for Sustainable Development (wbcsd). Available online: http://www.wbcsd.org (accessed on 2 October 2014).

4. Peattie, K. Green Consumption: Behavior and Norms. Annu. Rev. Environ. Resour. 2010, 35, 195-228.

5. Laroche, M.; Bergeron, J.; Barbaro-Forleo, G. Targeting consumers who are willing to pay more for environmentally friendly products. J. Consum. Mark. 2001, 18, 503-520.

6. Brandabur, R.E.; Tănase, L.D. Un altfel de consumator: Studiu asupra produselor ecologice. J. Online Mark. 2010, 4, 54-61.

7. Hamid, A.R. A Study on the Relationship between Consumer Attitude, Perceived Value and Green Products. Iran. J. Manag. Stud. 2014, 7, 329-342.

8. Schatzki, T.R. Social Practices: A Wittgensteinian Approach to Human Activity and the Social; Cambridge University Press: Cambridge, UK, 1996.

9. Peattie, K. Golden goose or wild goose? The hunt for the green consumer. Bus. Strateg. Environ. 2001, 10, 187-199.

10. Ottman, J.A. Green Marketing: Challenges and Opportunities for the New Marketing Age; NTC Business Books: Lincolnwood, IL, USA, 1993.

11. Neilssen, N. Business Strategy and the Environment: The Need for Information about Environmental Consciousness and Behaviour. Bus. Strateg. Environ. 1992, 1, 13-23.

12. Autio, M.; Heiskanen, E.; Heinonen, V. Narratives of "Green" Consumers-The Antihero, the Environmental Hero and the Anarchist. J. Consum. Behav. 2009, 8, 40-53.

13. Paco, A.; Raposo, M. Determining the characteristics to profile the green consumer: An exploratory approach. Int. Rev. Public Nonprofit Mark. 2008, 5, 129-140.

14. Chen, Y.-S. The Drivers of Green Brand Equity: Green Brand Image, Green Satisfaction, and Green Trust. J. Bus. Eth. 2010, 93, 307-319.

15. Baqer, S. True green consumers: An investigation of consumers' genuine willingness to share environmental responsibility. Glob. J. Bus. Res. 2012, 6, 37-48.

16. Menon, A.; Menon, A. Enviropreneurial marketing strategy: The emergence of corporate environmentalism as market strategy. J. Mark. 1997, 61, 51-67.

17. Schubert, F.; Kandampully, J.; Solnet, D.; Kralj, A. Exploring consumer perceptions of green restaurants in the US. Tour. Hosp. Res. 2010, 10, 286-300.

18. Tseng, C.-J.; Tsai, S.-C. Effect of consumer environmental attitude on green consumption decision-making. Pak. J. Stat. 2011, 27, 699-708.

19. Connolly, J.; Prothero, A. Green Consumption: Life-politics, risk and contradictions. J. Consum. Cult. 2008, 8, 117-145. 
20. Jansson, J.; Marell, A.; Nordlund, A. Exploring consumer adoption of a high involvement eco-innovation using value-belief-norm theory. J. Consum. Behav. 2011, 10, 51-60.

21. Peattie, K.; Crane, A. Green marketing: legend, myth, farce or prophesy? Qual. Mark. Res. 2005, 8, 357-370.

22. Lee, K. Opportunities for green marketing: Young consumers. Mark. Intell. Plan. 2008, 26, 573-586.

23. Raska, D.; Shaw, D. Is the greening of firms helping consumers to go green? Soc. Mark. Q. 2012, $18,40-54$.

24. Samarasinghe, D.S. A green segmentation: Identifying the green consumer demographic profiles in Sri Lanka. Int. J. Mark. Technol. 2012, 2, 318-331.

25. Bill, R. Green Consumers A Growing Market for Many Local Businesses. Available online: http://fyi.uwex.edu/downtowneconomics/files/2012/07/green-consumers.pdf (accessed on 15 May 2015).

26. Young, W.; Hwang, K.; McDonald, S.; Oates, C. Sustainable consumption: Green consumer behaviour when purchasing products. Sustain. Dev. 2009, 18, 20-31.

27. Ficher, C.; Bashyal, S.; Bachman, B. Demographic impacts on environmentally friendly purchase behaviors. J. Target. Meas. Anal. Mark. 2012, 20, 172-184.

28. Paco, A.; Raposo, M. "Green" segmentation: An application to the Portuguese consumer market. Mark. Intell. Plan. 2009, 27, 364-379.

29. Institutul Naţional de Statistică, Recensământul populaţiei şi al locuinţelor. (National Institute of Statistics, Census of population and housing) Available online: http://www.insse.ro/ cms/files/publicatii/pliante\%20statistice/04-recensamantul\%20populatiei.pdf (accessed on 2 November 2014).

30. Attitudes of European Citizens toward the Environment. Available online: http://ec.europa.eu/ public_opinion/archives/ebs/ebs_416_en.pdf (accessed on 15 May 2015).

(C) 2015 by the authors; licensee MDPI, Basel, Switzerland. This article is an open access article distributed under the terms and conditions of the Creative Commons Attribution license (http://creativecommons.org/licenses/by/4.0/). 